\title{
NOTES ON A WINTERING NORTHERN HAWK OWL IN MANITOBA
}

ROBERT W. NERO, Wildlife Branch, Box 24, 1495 St. James St., Winnipeg, MB. R3H OW9

The Northern Hawk Owl's usual habitat in Manitoba is in the Boreal Forest where it is considered "extremely rare," but it has even nested in the Aspen Parkland where it occurs mainly as an occasional winter visitant; Patsy Duncan listed it as a "rare irregular transient" in southern Manitoba. ${ }^{3}$ In winter 1991-92, a large number of Great Gray Owls and Northern Hawk Owls were seen in Manitoba and elsewhere in Canada. ${ }^{7}$ In southeastern Manitoba, Herb Copland and I saw 26 Great Gray and 23 Northern Hawk Owls in one day, 22 February; we joined a group effort (13 persons in seven cars) covering a larger area on 7 March, finding 23
Great Gray and 38 Northern Hawk Owls. ${ }^{4}$ By comparison, in winter 1993-94 both species were scarce. That winter was, as noted by Grieef, "one of the coldest that we have had in a number of years." Copland and I drove more than 1,870 miles $(3,000$ $\mathrm{km}$ ) on five outings between $11 \mathrm{De}$ cember and 20 March, finding not one Great Gray and only two Northern Hawk Owls, both of which we banded, at Fort Alexander Indian Reserve (Sagkeeng First Nation) and near Manigotagan. Four other Northern Hawk Owls were observed at Pinawa, Rivers, Vassar and Winnipeg. ${ }^{5,6,11}$

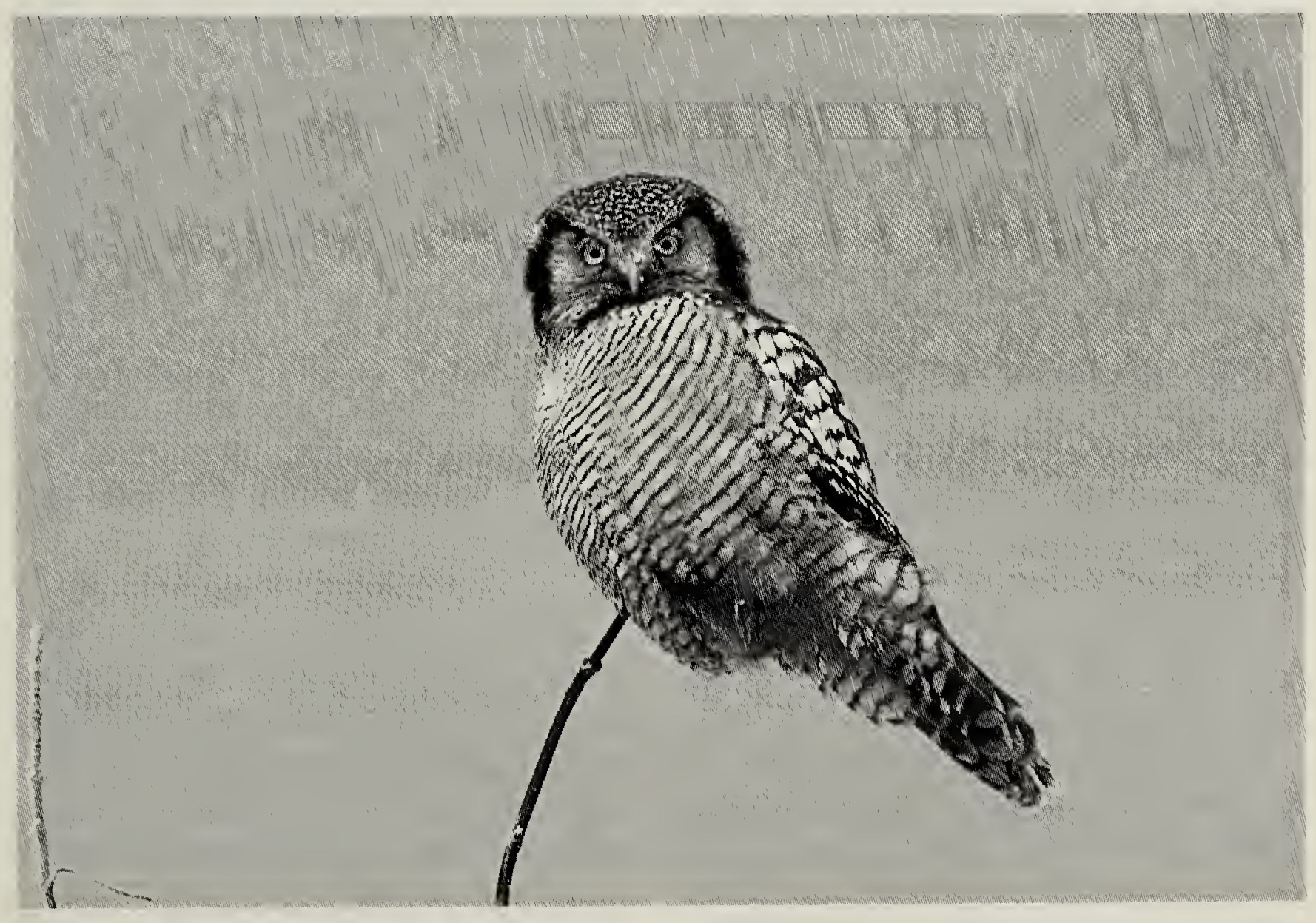




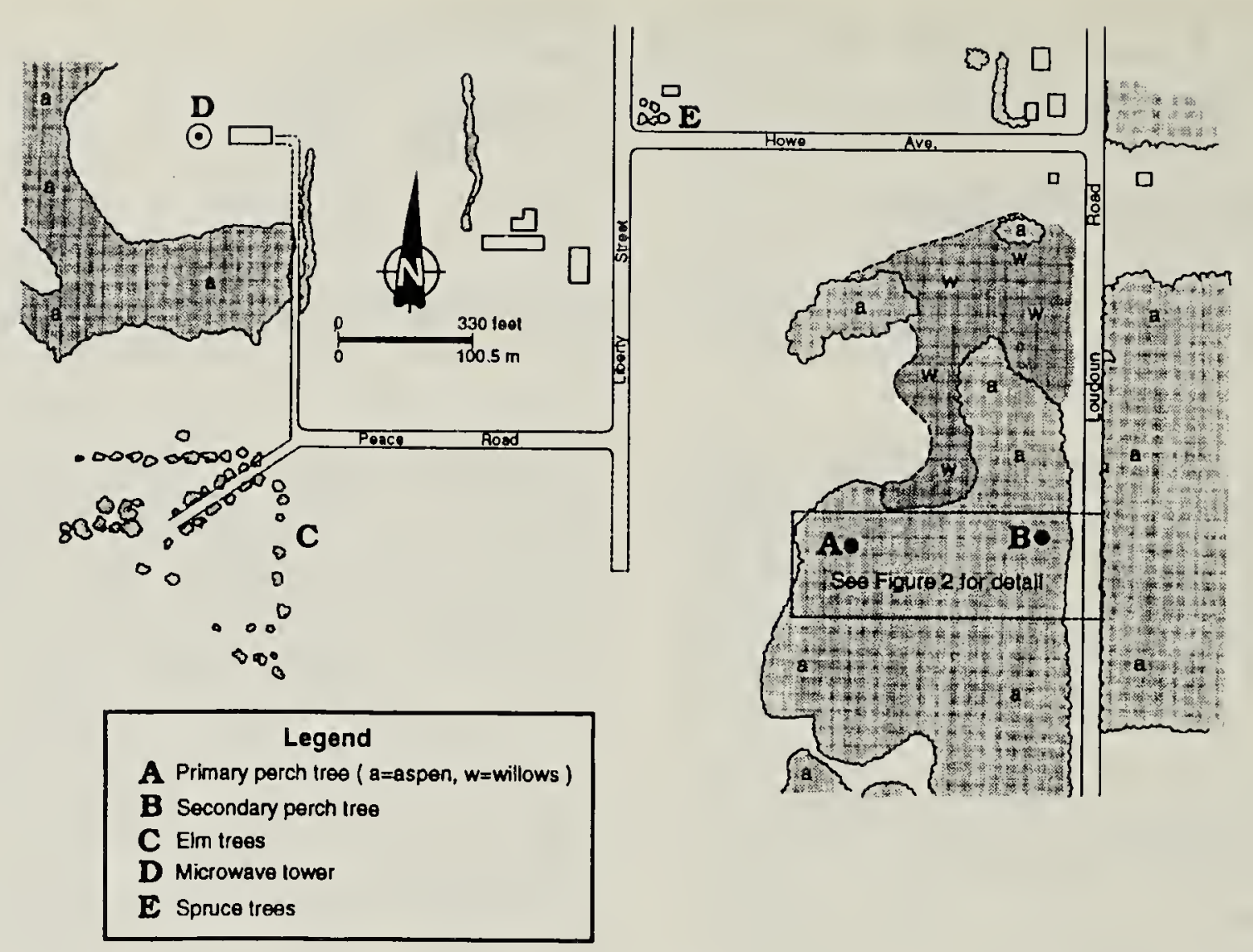

Figure 1. Winter territory of a Northern Hawk Owl in Winnipeg, MB, from 19 December 1993-18 March 1994 (from aerial photo and field notes).

Northern Hawk Owls appearing in Winnipeg in the past have not usually stayed for more than a few days, but this one was present from December 1993 to March 1994. It provided an opportunity to obtain some information on Northern Hawk Owl winter habits, a little known aspect of this species. This bird stayed in a portion of the suburb of Charleswood. The area lies southwest of extensive residential and commercially developed zones, but is relatively undeveloped. It is on the northern edge of continuous farmland, with scattered residences, cultivated fields, abandoned fields and some extensive aspen-oak woods. (In November 1991, two Northern Hawk Owls were recorded 2 miles $(3.5 \mathrm{~km})$ east and 4.7 miles $(6 \mathrm{~km})$ southeast of this site.) The area occupied by the owl is shown in Figure 1. A Trembling Aspen (Populus tremuloides) woods (right side of Fig. 1), where the owl spent most of its time, contained several mature aspens [9-11 $\mathrm{cm}$ (3.5-4.3 inches) diameter at breast height], a few Bur Oaks (Quercus macrocarpa) and ash, and some old dead willow clumps. The owl often perched on trees close to an adjacent well-travelled road (Loudoun) just as did a Northern Hawk Owl that wintered near Prince Albert, Saskatchewan in 1991-92. That bird, which spent the entire winter "within half a kilometre" of the Barton residence, had "three or four favourite lookout trees very close to the road." Our bird, so far as I'm aware, stayed within the 50.1 ha (123.8 acres) shown in Figure 1.

One particular tree, an aspen about $13.7 \mathrm{~m}$ (45 feet) tall, provided a perch from which the owl could see in all directions over its winter territory (Figure 1-A). It often sat on or near the top of this tree, especially early and late in the day. Sometimes it sat lower down, as much as 1.2$1.5 \mathrm{~m}$ (4-5 feet) below the top; from a distance one had to look hard to see 
if it was close to the trunk. Perched on top, however, it was conspicuous. I called this the primary perch tree (PPT). A second tree, an aspen about $9.1 \mathrm{~m}$ (30 feet) tall and to the east of the PPT, was used as an alternate or secondary perch tree (SPT) (Figure 1-B). The owl also hunted from trees at the north end of the willows, from hydro poles along the roads (especially along Peace Road), and from the elms to the west (Figure 1-C). One or two elms, in particular, were often used. Two sites seemed to be preferred hunting spots, the grassy fields near the elms and the weedy lowland at the north end of the aspen woods. Heavy grass and, as I discovered after the snow began to disappear, a variety of junk lying in the willowsedge area just off Loudoun Road, sheltered an abundance of voles. Most hunting seemed to take place in late afternoon and evening and early in the morning. The few times I saw it capture prey, it looked as if it was finding prey visually. Voous notes: "Hunting mostly by day, the Northern Hawk Owl looks around for prey from an exposed treetop or other commanding post. ... On other occasions it dashes with astonishing speed low through the forest and over and around shrubs like a Sparrowhawk, soars like a falcon or hovers like a Kestrel watching for moving prey. In all these respects it behaves more like a diurnal raptor than an owl." ${ }^{13}$

Jan E. Collins was the first to see this bird, on 19 December 1993. A resident of ('harleswood, Collins trains his dog in this area. Since he had been going there at least twice weekly from the third week in November onwards, it seems likely that the first time he saw the bird was about the time it arrived in that particular area. In the afternoon of 19
December, Collins noticed it sitting on a hydro pole near the elm trees where he regularly parks his vehicle (west end of Peace Road). Shortly after pointing it out to his son, Darin Kozak, the owl flew over the adjacent open field, hovered, plunged into the snow, then returned to the pole to eat its prey. Collins saw it again on 24 December, and the next day reported it to a member of the Manitoba Wildlife Branch staff.

I heard about the bird on 6 January 1994 and that evening found it in the same vicinity. On 8 January, Patsy and Jim Duncan and I attempted to capture the bird for banding, but it showed little interest in our lures. In fact, the owl sat on the same hydro pole where Collins had first seen it and ignored our live mouse running below it on the road. On three later days, Bob Berger and I attempted in vain to lure the owl to a net or trap. A live gerbil, loose on the snow as the owl perched about 20 feet away one cold day, held its attention for several minutes. Once it looked like it might come down to my net, but it flew down to the ground behind me where it seized a vole. The Duncans had similar results with Northern Hawk Owls in January 1987 in northern Minnesota. ${ }^{8}$

Judging by the owl's lack of response to our live bait, it was well fed, doubtless the result of a local high vole population. And presumably this was part of the reason the owl spent the winter here within a relatively small area. Throughout winter, small mammal burrow openings in the snow were numerous. After the snow cover disappeared, vole eat-outs could be seen in the heavy grass where the owl had often hunted. As the snow melted away, a few dead voles were found on snowmobile tracks, apparently crushed by 
the vehicles passing over them.

Through January, despite severe low temperatures and strong winds, the owl could often be found perched in the open on top of hydro poles or trees. Because this area is only a few minutes from my home, over the next two months I was able to show the owl to more than two dozen people, including some avid photographers. The Northern Hawk Owl was also viewed by a number of birders. As is characteristic of the species, this bird was bold, accepting people and dogs unreservedly. Often it allowed us to approach to within $6 \mathrm{~m}$ (20 feet) of its perch. On two occasions when it was perched on top of a tree, it refused to budge even when I shook the tree. It simply looked down at me as if wondering what I was up to. Others have had similar experiences with this bold species. Bent notes: "It has repeatedly shown no concern when closely approached and has even been captured by human hands." ${ }^{2}$ During a recent influx of Northern Hawk Owls in Saskatchewan, according to James, "one person was even able to pet an owl!" Ray Tuokko (pers. comm. 1994) told me how one winter at Lac du Bonnet he climbed up a tree to see how close he could get to a Northern Hawk Owl sitting on the top twig. He nearly touched it before it flew.

Twice I saw the Northern Hawk Owl being harassed by a Hairy Woodpecker, and other observers told me they'd seen this happen a few times. The woodpecker's brief swooping flights towards the owl usually perched at the top of a tree - seemed to have no effect on the owl. Three Black-capped Chickadees, apparently local residents, for I saw them on several days, frequently made passes at the owl.
Once, a small flock of Common Redpolls fluttered excitedly near the owl.

Initially, it was unclear how long the Northern Hawk Owl would remain, and I had only moderate interest in it. About 9:00 a.m. on 5 February, I saw it cast a pellet. After the owl moved away, I retrieved the pellet and, by digging in the snow, found a second one. I became intrigued. Thereafter, I looked for pellets in the snow wherever I saw the bird perched, as well as under hydro poles and isolated trees in the area. In the end, I visited the area on about 30 days, from 8 January to the end of March. At first it didn't occur to me to take notes, but from 1 February onwards, when I began making frequent visits, I carried a notebook and pencil, recording a few observations.

Often, the owl could be seen out in the open on some conspicuous perch, but there were days when we couldn't find it. One bright, cold January day, the owl moved from a treetop perch on the edge of the woods back into the woods. We found it about $18.2 \mathrm{~m}$ (20 yards) inside the woods and about $4.3 \mathrm{~m}$ (14 feet) up near the trunk of an aspen. If we hadn't seen it fly in that direction, it could easily have been overlooked. Conspicuous when sitting up high in the open, it blended in surprisingly well when perched on a branch inside the shelter of the woods. I attempted to follow it about on a few occasions, though snow depth and low temperatures (and my age!) made this difficult. One day I was excited to see it fly up onto an old American Robin nest on the side of an aspen trunk. It sat in the nest, playing with nesting material, moss in this case, some of which fell onto the snow. I thought at the time that perhaps it had a mouse cached there, but after five or six minutes in 
the nest, the owl moved away. Owl whitewash on the trunk of the tree and the edge of the nest, however, showed that the bird had been there before. A month and a half later, I found whitewash, presumably from the owl, on yet another robin nest in another part of the woods. I surmised that these were roost-sites or resting places, the flat surface of the old nests possibly being attractive to the owl. In this woods, as I discovered, there were practically no other features that afforded the bird a platform, something reminiscent of the hollow at the top of broken tree trunks such as Northern Hawk Owls often use as a nest site. ${ }^{2,9,12}$

I had followed the owl a few times, trying to see where it went to roost for the night. I expected it to go into some tree cavity late in the evening. At $-30^{\circ} \mathrm{C}$, and that winter there were many nights at or below this temperature, this seemed logical. I spent a few cold evenings standing around in the woods watching the owl on its primary perch tree, waiting to see where it would go. My evening vigils yielding puzzling results with the bird suddenly dropping down and away and disappearing in the woods, and not always in the same direction. It was frustrating. My luck changed on 10 March. Upon my arrival at the site at 4:00 p.m., I found the owl on top of the tree. It soon flew away to the east and several minutes later I found it on top of the secondary perch tree. At 4:30 p.m., as I was making my way back to the PPT, the owl came flying through the woods with a vole in its talons, then fluttered down to perch only $1.2 \mathrm{~m}$ (4 feet) above the snow on the broken end of a leaning deadfall.

Here, to my delight, for the owl was now only about $9 \mathrm{~m}$ (30 feet) from me, it proceeded to eat part of the vole, first plucking off bits of skin and fur that floated away. When my dog came trotting by directly under it, the owl slowly flew away with the remains of the vole. On the snow beneath this perch, which was streaked with whitewash, I found several pellets, plus a heavy deposit of feces in a slight depression - this had the appearance of a nocturnal roost-site! Repeated defecation had melted the snow which then refroze to a hardened layer of feces and ice. If not actually an overnight roost-site, it was clear that the site had been used several times for feeding and resting. Hurriedly looking about for the telltale whitewash on limbs and twigs, I quickly found five similar stations, all within a relatively small radius. Before long I had gathered 36 pellets. I was elated. Prior to this time I had found only 20 pellets altogether.

It was now getting late, so I headed out; on the way, I found the Northern Hawk Owl part way up the primary perch tree. A few minutes later, at 5:00 p.m., it went to the top. At $6: 20$ p.m. and again at 6:30 p.m. it sang briefly, short mellow bursts lasting 5-10 seconds. At 6:38 p.m. it fluttered down and low through the trees to the east. I guessed that it was heading for the roost area about 50 yards away. I had first noted it singing on 5 March. That day, I arrived at 5:30 p.m. and heard it sing, a tremulous, warbling call, at 6:05 p.m. The call lasted about 15 seconds. The owl sang every 2-5 minutes up to $6: 20$ p.m., its whole body quivering with the exertion. At 6:35 p.m. it flew off. In 1919, Alberta naturalist A.D. Henderson noted (quoted by Bent) that: "The calls ... are a trilling whistle, wita-wita-wita, etc., which is the love call of the male. I have never heard it uttered by the female. It is one of the signs of early spring, being first heard in February and 


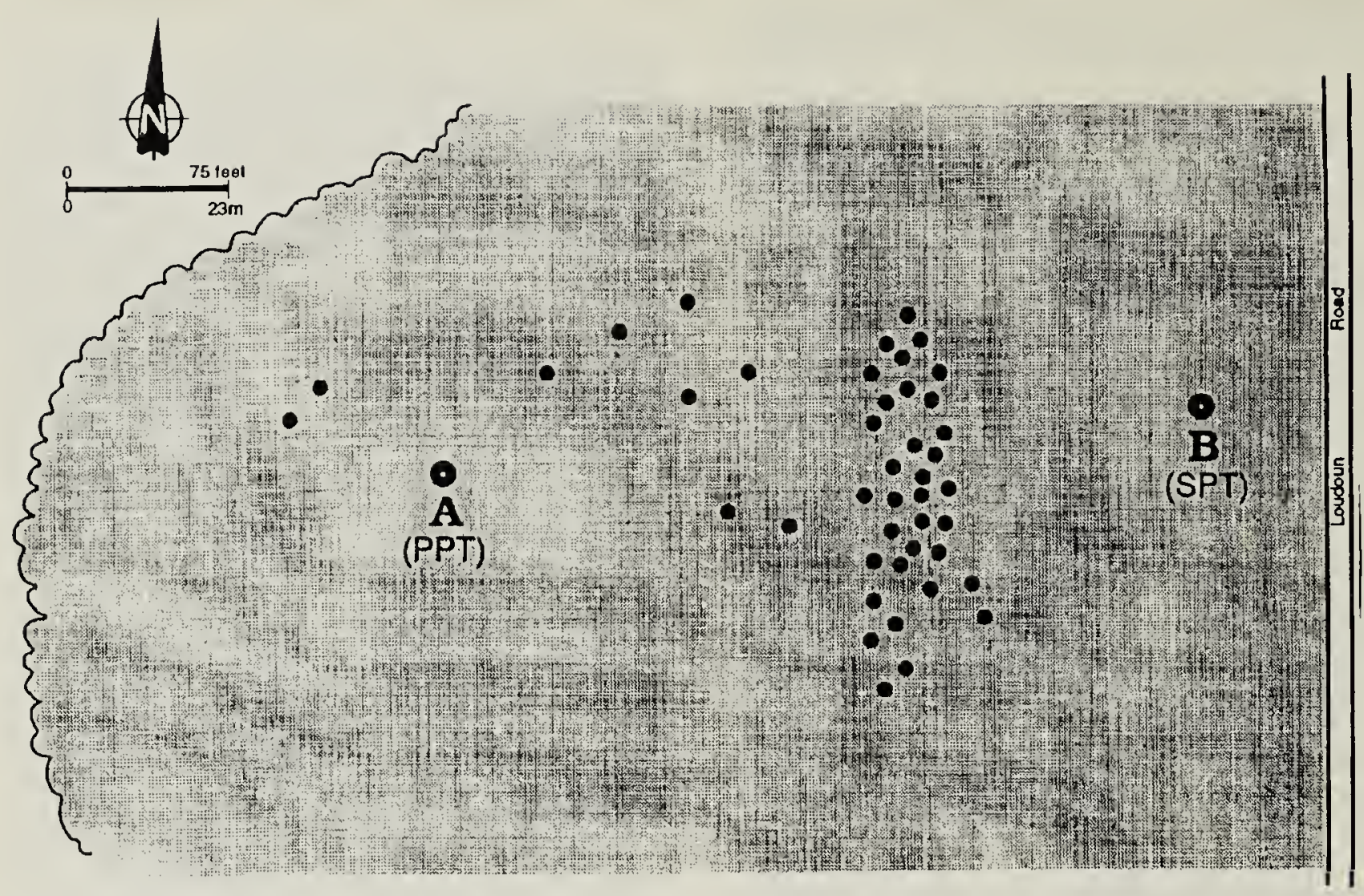

Figure 2. Primary perch tree (PPT) - A; secondary perch tree (SPT) - B; and associated roost-feeding sites for a Northern Hawk Owl wintering in Winnipeg, MB, 19 December 1993-18 March 1994 (based on field measurements).

through March and April." 2 Voous states: "Its trilling territorial song comprises a high-pitched, monotonous series of whistles ... resembling the sounds hoo-hoo-hoo-hoo or ulululu. It is the call from which Linnaeus is supposed to have derived the bird's specific name ulula. ..."13

Two days later, by digging through the compacted snow at the same roost sites, I collected 22 more pellets. In the end, by searching the entire woods, I discovered that the majority of the roost sites lay within a concentrated area of about $54.8 \mathrm{~m} \mathrm{x}$ $18.2 \mathrm{~m}$ (60 yards $\times 20$ yards) (see Figure 2), approximately 45.7 m (50 yards) east of the primary perch tree. I flagged each site, and by digging down through the snow and frozen feces at these sites with a garden trowel, and by repeated visits as the snow melted away, collected more than 100 pellets. Several sites later were flooded to a considerable depth by meltwater, but even then I was able to find a few pellets under water. Other sites were examined after the snow disappeared and exposed the ground surface. In a few instances I chopped pellets out of the ice. Most of the pellets, however, were found in the snow, and I believe that they had been dropped only after there was snow on the ground. This would fit with the apparent arrival of the owl on 19 December.

Judging from the number of pellets found, roost-sites within this close array were each used on from one to eight nights. Most of the additional roost-sites found at various distances from this point had only one pellet, suggesting limited use. A few pellets, mostly small ones, were found beneath the PPT and SPT. Feeding or roosting perches (or a combination) were on aspen deadfalls, old fallen willow clumps, and close to the trunk on branches of live aspens of various sizes. Actual perches, as identified from whitewash on twigs, trunks, etc., 


\begin{tabular}{|c|c|c|}
\hline \multicolumn{3}{|c|}{$\begin{array}{l}\text { Table 1. NORTHERN HAWK OWL PREY ITEMS RECOVERED FROM PELLETS FOUND IN } \\
\text { WINNIPEG } 19 \text { DECEMBER 1993 - } 18 \text { MARCH } 1994\end{array}$} \\
\hline Species & Number & $\%$ of Total \\
\hline Short-tailed Shrew & 2 & 0.8 \\
\hline Meadow Vole & 248 & 98.0 \\
\hline Red-backed Vole & 2 & 0.8 \\
\hline Deer Mouse & 1 & 0.4 \\
\hline Total & 253 & 100.0 \\
\hline
\end{tabular}

appeared to range in height from 0.9-3.3 $\mathrm{m}$ (3-11 feet) abcve the snow, with a majority in the 1.5-2.2 $\mathrm{m}$ (5-8 feet) range. The primary perch tree top was visible from most of these sites. The evidence suggests that the owl, in the apparent absence of a tree cavity in this woods (if, indeed, they roost in cavities), spent each night perched at one of these roost-sites.

Assuming that the Northern Hawk Owl arrived on or about 19 December, and departed on 18 March, it was resident for about 90 days. The more than 250 prey items recovered (Table 1) must, therefore, represent a good portion of its intake during that period. Generally, owls regurgitate one pellet daily, though this varies with the timing of ingestion of prey. Thus, the more than 100 pellets collected probably account for a majority of the pellets cast by this bird. A few pellets up to $7.6 \mathrm{~cm} \mathrm{(3}$ inches) in length contained remains of four animals; a dozen or more pellets held three. The majority held two animals, with many small pellets holding only one. Generally, smaller pellets were found under perches out in the open, places where the owl spent less time. The larger ones were found mainly beneath the presumed night roost-sites.

The appearance of undigested parts in several pellets was noted. Whole tails, feet, vertebral columns still linked by tendons, even strips of flesh on a few leg bones were found, suggesting a surfeit of food. An uneaten posterior half of a Short-tailed Shrew left lying on the snow surprised me, as did a vole, the foreparts of which had been picked clean; the owl had even carefully picked the brain out of the cranium before dropping the carcass. I assumed that these were the Northern Hawk Owl's discards for they were found under trees that it frequented.

The total number of prey animals recovered from pellets was 253 (see Table 1). The Northern Hawk Owl was present for at least three months or approximately 90 days (19 December-18 March). Hence it would appear that minimally it consumed about 2.7 prey animals daily. Two to three voles may not seem like a lot for a bird that is capable of taking prey as large as ptarmigan, but voles weigh an average of 45 grams (pers. comm. J. Duncan). When captured for banding on 13 March, the Northern Hawk Owl weighed 350 grams. The high percentage of Meadow Voles in the sample is not unexpected, given the abundance of this species in this region at the time. Lane and Duncan found that Meadow Voles were prominent in the diet of Northern Hawk Owls during the breeding and non-breeding season. ${ }^{8}$

When Jim and Patsy Duncan were available on 13 March, we decided to make one more attempt to capture the owl. Armed with a mounted Great Gray Owl from the Wildlife Branch, live mice, Bal-Chatri trap, 
etc., we met at the area at 3:00 p.m., but the owl was nowhere in sight. I had wanted to show the roost-sites to the Duncans, so we walked into the woods. And there, first spotted by Patsy at one of the roost-sites, sat the owl, only about 7 feet $(2.1 \mathrm{~m})$ above the snow. Leaving Patsy to keep an eye on the owl, Jim and I raced back to the cars for the gear. It was a dark day with a strong south wind and a little rain, but I had the mounted bird in a black plastic bag, so back we went to catch the owl. Two live mice in the trap placed on the snow within 20 feet $(6 \mathrm{~m})$ of the owl drew little response. Next we strung a mist-net and unveiled the Great Gray Owl. The Northern Hawk Owl flew a few feet towards the mounted bird, then stopped as if uncertain how to respond. Finally, remembering that $I$ had a piece of snare-wire in the car, I hurried back again. By the time I returned, Jim had an 8-foot $(2.4 \mathrm{~m})$ branch ready. We hastily fastened a snare on the end of his pole, then, while I tried to divert the owl's attention with the mounted bird in my arms, Jim attempted to slip the noose over the little owl's head. Each time the wire brushed against its head the owl ducked away, but it stayed on the perch. Finally the snare worked, we had the owl. An immature male, we took it back to the cars to band, then returned to the woods to release it in the same place. Three minutes later, after preening its plumage, it turned to face us as if wondering what was going to happen next.

The next day, I heard it singing early in the morning in the vicinity of the primary perch tree. On the following day, 15 March, I spent 10 hours in the area (7:10 a.m.-4:30 p.m.), staying within sight of the owl for a good portion of that time. When I arrived, the owl was on its primary perch tree. At 7:20 a.m. it sang once, then a few minutes later it disappeared. At 8:30 a.m. I discovered it in the elms to the west (see Figure 1) where I hadn't seen it for a month. It sang strongly from there at 8:45 a.m., then flew north to perch on a dead tree in an aspen clump where l'd never seen it before (and there were no feces underneath). At 9:00 a.m. it sang repeatedly from this tree and I noted that it "seems agitated." Shortly, it flew to a hydro pole at the east end of Peace Road, on the way giving a "bridling" display, that is, gliding on outspread set wings with its head raised. I've seen Great Gray Owls do this occasionally, and have interpreted it as a territorial display.

The Northern Hawk Owl soon returned to the same elm tree (9:04 a.m.) then slipped out of my sight (9:15 a.m.). It reappeared over the north aspen grove, and for three minutes alternately flapped and glided, "planing like a Mourning Dove." In this mode it circled three times at a height of perhaps 50 feet $(15 \mathrm{~m})$ around a microwave tower (Fig. 1-D) before returning to the elm. Then, facing the tower, thus looking to the north, it sang again (9:28 a.m.) and two minutes later sang even louder. I didn't know what to make of this. Was there a nest tree to the north? Did it have a mate in that woods? Was it going to leave? It was reassuring to watch it fly back "home" to the primary tree at 9:35 a.m. For the rest of the day I searched in the main woods for other roost-sites, paced off the area, etc., noting that the owl was on and off the PPT at intervals.

I returned to the area two days later (17 March) at 3:20 p.m. An hour later the owl appeared on the PPT, then at 4:40 p.m. it flew low through the trees to the northeast. Hurrying in that direction, I found it perched on a branch of a small dead tree, about $2.4 \mathrm{~m}$ (8 feet) above the snow. A 
dead vole l'd found along the way on a snowmobile track lured the owl to within 20 feet $(6 \mathrm{~m})$ after 1 tossed it onto the snow several times. I then draped it over a branch. The owl stared hard at the vole, then turned and flew back to its original perch on the dead tree. Seconds later it flew onto the trunk of that tree like a woodpecker and, to my surprise and delight, withdrew the posterior half of a dead vole from a hole in the tree. (Later, I found another dead vole on the ice beneath this site, presumably a prey item that had fallen from the hole.) The hole, about an inch (2.5 $\mathrm{cm})$ wide and 3 inches $(7.6 \mathrm{~cm})$ high, appeared to be an old excavation made by a woodpecker. The owl carried its half-a-vole $15 \mathrm{~m}$ (50 feet) to another perch (used before, for I later found whitewash and a pellet underneath the tree) to feed on it. Despite the noisy snow, frozen overnight, I was able to approach to within $2.7 \mathrm{~m}$ (3 yards) of the owl, perched some $2.4 \mathrm{~m}$ ( 8 feet) above the snow, so I had a good view. First, he removed and dropped the entrails, then peered down as if annoyed, for the gut-string was swinging from a twig it had fallen onto. As the owl pinched off bits of skin and fur (found at several feeding stations) and nibbled at the vole's flesh, I realized that this was a fastidious eater. (Judging by the numerous badly crushed skulls in its pellets, it spent some time nibbling the heads of its prey. Often, especially in large pellets containing more than one prey item, only the palatine bones and molars were intact. Whole crania, with mandibles still in place, tended to occur in smaller pellets. I learned this in the process of picking the crania and mandibles out of the 100 plus pellets.) When my dog passed below the owl showed no special concern. After completing his meal, the owl cleaned his bill, rubbing it vigorously on the branch it was on. It flew off only when I tried to get closer, heading back to the PPT.

Earlier, on 22 February, l'd seen the owl peer into another woodpecker excavation. At 4:45 p.m., I found the owl perched on an oak east of its usual woods, across the road, an area where l'd seen it fly for a brief period on a few previous occasions. I thought perhaps this was where it roosted, for late one evening it seemed to head in that direction. From the oak tree it fluttered down to an old decayed aspen stub and then peered into a cavity about $2.7 \mathrm{~m}$ (9 feet) up that I hadn't noticed before. The hole was about $5 \mathrm{~cm}$ (2 inches) wide and $7.6 \mathrm{~cm}$ ( 3 inches) high. The owl looked back at me, and I foolishly thought it was showing me its roost site. It fluttered away, low and slow, to an old broken aspen, so I hurried to look for signs of use below the cavity tree, but there was nothing. I watched the owl for the next half hour as it moved in the same slow flight from one perch to another, calmly preening between flights. I could find no whitewash at any of these perches. At 5:25 p.m., it flew back across the road and up to the PPT. Only after seeing the owl pull the half-a-vole out of the cavity (above) did I realize that these were cache sites, places in which to hide excess captured prey. A recent report by McNair of caching in the Northern Hawk Owl overlooked an account of this behaviour by Patsy and Jim Duncan; the Duncan's observed Northern Hawk Owls "caching prey items on several occasions, before and during nesting." ${ }^{8,10}$ McNair watched a Northern Hawk Owl, a bird he presumed to be off its breeding grounds, eat the anterior half of a vole, and then store the remaining half on top of a telephone pole. ${ }^{10}$

All winter long, l'd reminded myself that one day the Northern Hawk Owl likely would leave to return to its 
presumed far northern breeding grounds. Part of my reason for visiting the area daily, especially late in the season and after we had banded it, was to try and record its last day here. As it happened, I was fortunate to be watching the owl at apparently the very time it departed. This was on 18 March. When I first found it that day at 3:45 p.m., the owl was on the primary perch tree, but below the top. At 3:55 p.m. he gave a big stretch, first with one wing down, then with both wings overhead while stretching his tail. My notes read: " $4: 45$ - he's up on top of the tree; 4:58 - he twitches his tail, very alert, looks ready to leave the tree; 5:02 - he turns and flies off, dropping down fast to the north." I hurried after him, not yet aware what he was up to, making my way through the wet snow and water out into the open. I couldn't see him, but a few minutes later I discovered him perched atop a large spruce tree beside a house about 440 yards (402 $\mathrm{m})$ to the northwest (Fig. 1-E). Heading that way, and wondering what on earth he was doing in that yard, where l'd never before seen him, I saw him drop away, flying low to the north. It was my last glimpse of the Northern Hawk Owl. After first going back to check the primary perch tree (thinking that he might have eluded me and returned), I drove around for 40 minutes, searching the area for $3.2 \mathrm{~km}$ (2 miles) to the north. I thought perhaps I might still find him somewhere, but at 5:45 p.m. I noted: "I think he's gone up north!" To verify that the Northern Hawk Owl had left the area, I checked the area daily for the next four days and returned irregularly for several days thereafter. The owl was not seen again.

Acknowledgements I owe thanks to the following persons for assistance in various ways: Robert P. Berger, Jan E. Collins, James R. Duncan,
Patricia A. Duncan, Tim Garton, Gerry Jones, Rhonda O'Grady, Keila Orbanski and Jaimie Ruggles. The figures were rendered by Computer Graphics Support Services, Manitoba Natural Resources. Gordon G. Graham kindly typed the manuscript for me. I am especially grateful to Jim Duncan for taking time from his busy schedule to identify the prey remains.

1. BARTON, M. 1992. Fishing for Northern Hawk Owls near Prince Albert. Blue Jay 50:80.

2. BENT, A.C. 1938. Life histories of North American birds of prey. Part 2 U.S. Natl. Mus. Bull. 170. 482 pp.

3. DUNCAN, P.A. 1991. Status report on the Northern Hawk Owl Surnia ulula. COSEWIC, mimeo. $58 \mathrm{pp}$.

4. GRIEEF, G. 1992. Bird News. Manitoba Naturalists Society Bull. 17:10.

5. — 1994. Bird News. Manitoba Naturalists Society Bull. 20:10.

6. 1994. Bird News. Manitoba Naturalists Society Bull. 20:13.

7. JAMES, P.C. 1994. Northern Hawk Owl irruptions in Saskatchewan: 1990-91 and 1991-92. Blue Jay 52:25-28.

8. LANE, P.A., and J.R. Duncan. 1987. Observations of Northern Hawk-Owls nesting in Roseau County. The Loon 59:165-174.

9. LANG, A.L., J.R. DUNCAN, S. RAMSAY and J.D. RISING. 1991. Great Gray Owl and Northern Hawk Owl nests at Churchill, Manitoba. Blue Jay 49:208-214.

10. MCNAIR, D.B. 1994. Caching by an irruptive Hawk-Owl. Blue Jay 52:216217.

11. PARSONS, R. 1994. Bird news: Christmas Bird Count results. Manitoba Naturalists Society Bull. 20:1011.

12. SEUTIN, G. 1990. The Northern Hawk-Owl nesting at Churchill, Manitoba. Blue Jay 48:115-116.

13.VOOUS, K.H. 1988. Owls of the northern hemisphere. William Collins Sons \& Co. Ltd., Toronto. 320 pp. 